\title{
A review of optimal systems for organic production of blueberry and blackberry for fresh and processed markets in the northwestern United States
}

Bernadine C. Strik

Department of Horticulture, Oregon State University, 4017 Ag. \& Life Sciences Bldg., Corvallis, OR 97331, USA. E-mail address: bernadine.strik@oregonstate.edu

Keywords: weed management; fertilization; economics; yield; mulch; compost

\begin{abstract}
\end{abstract}
Various production systems have been evaluated in blackberry (Rubus L. subgenus Rubus Watson) and northern highbush blueberry (Vaccinium corymbosum L.) in certified organic research trials for 5 and 8 years, respectively, in Aurora, OR, USA (lat. $45^{\circ} 16^{\prime} 47^{\prime \prime} \mathrm{N}$, long. $122^{\circ} 45^{\prime} 23^{\prime \prime} \mathrm{W}$ ) and are reviewed here. Treatments included cultivar, weed management, and fertilizer source in both crops; planting system, use of municipal yard debris compost, and fertilizer rate in blueberry; and effectiveness of liquid sources of fertilizer through the drip irrigation system, training time, and impact of withholding irrigation after fruit harvest in blackberry. In blueberry, cumulative yield per plant (2008-2014) averaged 21\% greater on raised beds than on flat ground. A black, woven polyethylene ground cover (weed mat) offered the most economical method of weed control, as compared to a mulch of municipal yard debris 
compost topped with sawdust or sawdust alone. Mulching with weed mat increased cumulative yield compared to the organic mulches, but there was little effect of mulch type on fruit quality. Plants grown with weed mat had a higher shoot-to-root ratio during establishment and required more irrigation water be applied. Addition of yard debris compost to the mulch increased soil and leaf potassium $(\mathrm{K})$, but had little effect on plant nitrogen $(\mathrm{N})$. However, when this compost was used as an amendment prior to planting, soil $\mathrm{pH}$ increased to levels above the recommended range for blueberry. Some cultivars were less adapted to the various fertilizer sources and production systems tested. Trailing blackberry plants grown with weed mat produced $25 \%$ and $100 \%$ higher yield than plants grown with hand-weeding and without weed control, respectively, making this the most economical weed management option. We found no effect of post-harvest deficit irrigation on yield over 2 years. There was little effect of fertilizer source on blackberry yield or fruit quality in processed or fresh production systems. Cultivar differences in adaptation to organic production systems and susceptibility to insect pests were noted. Organic sources of fertilizer contain high levels of nutrients other than N, particularly phosphorus, K, and calcium. The addition of these nutrients when using organic fertilizers, even when they are not required by the plants, must be considered in these production systems. The cost of organic fertilizers tested ranged from $\$ \mathrm{US} 5.60$ to $\$ 17.95$ per $\mathrm{kg}$ of $\mathrm{N}$ and varied by method of application. Liquid sources of fish and grain blends were successfully fertigated during the study with little impact on emitter performance. Since our research began, weed mat has become very common in organic as well as conventional blueberry fields in the Pacific northwestern United States thus reducing costs of herbicides and hand weeding.

\section{Introduction}


The Pacific northwestern United States is an important region for production of cultivated blueberry (Vaccinium spp.) and blackberry (Rubus L. subgenus Rubus Watson) accounting for $20 \%$ and $45 \%$ of the total U.S. harvested area in 2012, respectively (U.S. Department of Agriculture, 2014). Most of the blueberries grown in Oregon and Washington are northern highbush cultivars (Vaccinium corymbosum L.; e.g., 'Duke', 'Draper', 'Liberty', ‘Aurora') harvested by hand or machine for fresh ( $\sim 50 \%$ of production) and processed markets. In contrast, most of the blackberry production in this region is in Oregon with trailing blackberry cultivars (e.g., Marion, Black Diamond) accounting for over $95 \%$ of the planted area, and erect (e.g., Navaho, Ouachita) and semi-erect (e.g., Chester Thornless, Triple Crown) cultivars grown on the remaining area (Strik and Finn, 2012). Trailing types are predominantly grown for processed markets (individually quick frozen, bulk frozen, puree, and juice) and are harvested by machine, whereas those grown for fresh market are harvested by hand.

The proportion of total U.S. blueberry and blackberry production grown on certified organic and exempt organic (less than \$US5,000/year gross income and not requiring certification) farms was relatively small at 3\% for each crop in 2008 (U.S. Department of Agriculture, 2010). However within the U.S., the Pacific northwestern region accounted for 39\% and $49 \%$ of the total blackberry and blueberry organic area planted in 2008, respectively. The certified organic area has grown considerably since the last survey was conducted in 2008, particularly in blueberry where the certified area increased to an estimated 915 ha in Oregon and Washington in 2011, 55\% of total U.S. organic blueberry area (Strik, 2014). By 2014, the organic blueberry area in Oregon and Washington accounted for about $20 \%$ of total blueberry area planted. 
Growth in organic blueberry and blackberry production continues as consumer demand

72 for organic products remains strong, creating a $20 \%$ to $200 \%$ price premium for organic fruit.

73 This region is also considered to have advantages for organic production, including reduced

74 weed and disease management costs in the dry, low-humidity summers, and the absence of some

75 important diseases and insect pests that cause losses in other production regions (Strik et al.,

76 2015, 2007; Strik and Yarborough, 2005).

77 Research on organic production systems in this region was strongly influenced by the

78 industries, who requested trials on organic production, helped fund the studies through grants,

79 and guided the research through advisory boards (Strik et al., 2015). When the research studies

80 were initiated (2006 and 2010 for organic blueberry and blackberry, respectively) there were two

81 production guides for organic highbush blueberry and one for organic blackberry in North

82 America (Krewer and Walker, 2006; Kuepper and Diver, 2004; Kuepper et al., 2003). The

83 recommendations in these guides, however, were based on anecdotal information with little

84 research to compare methods. Furthermore, there was no information on organic production

85 systems available for trailing blackberry specifically grown for high-value processed markets,

86 particularly whether machine harvest could be used (as is common in conventional production).

87 Growers interested in the processed blackberry market had questions as to whether labor-saving

88 machine harvesting technology can be used in organic systems where even "beneficial" insects

89 could become harvest contaminants. Key challenges to rapid expansion of certified organic

90 blueberry and blackberry production were thus identified including greater production costs

91 and/or inputs (particularly for fertilization and weed management), limited options for disease

92 and insect control associated with greater risk, and reduced yields of organic plantings (whether 
93 perceived or real). Growers were concerned about whether returns would be enough to more than

94 offset the expected higher costs of organic production (Strik, 2014).

95 The objectives of the research trials were to evaluate crop-relevant production systems

96 and assess their impact on plant growth and nutrient status, yield, fruit quality, and economics of

97 production from establishment through maturity in blueberry and blackberry. In blueberry, the

98 impact of planting method, cultivar, mulch, and fertilizer source and rate were evaluated. In

99 blackberry, weed management options, training time, and deficit irrigation were evaluated in two

100 important cultivars grown for the machine-harvested, processed market. In addition, cultivar

101 adaptation and fertilizer source were evaluated.

102 This manuscript is intended to be a review of the organic production systems research

103 conducted on blueberry and blackberry in Oregon, USA. I will first describe the key

104 methodologies used in the various organic trials conducted over the last decade; the original

105 studies, where more information is provided on methodology and statistical analyses used, are

106 cited where appropriate. Key results and discussion items are provided.

107

108 2. Materials and methods

109 Long-term organic systems trials were established at Oregon State University's North

110 Willamette Research and Extension Center (NWREC; Aurora, OR, USA; lat. 45 ${ }^{\circ} 16^{\prime} 47^{\prime \prime} \mathrm{N}$, long.

$111122^{\circ} 45^{\prime} 23^{\prime \prime} \mathrm{W}$ ) for blueberry in 2006 and for blackberry in 2010. Each planting was certified

112 organic prior to the first fruit harvest year by a USDA-accredited agency (Oregon Tilth, Certified

113 Organic, Corvallis, OR). The soil is mapped as a Willamette silt loam (a fine-silty, mixed,

114 superactive mesic Pachic Ultic Argixeroll) with an organic matter content of 3 to 4\%. In 
115 addition, a grower-collaborator trial evaluating the effect of fertilizer source in fresh market

116 blackberry cultivars was included and is described below.

118 2.1. Blueberry

\subsubsection{Blueberry organic systems trial}

A 0.4-ha research trial was planted in October 2006 and was transitional in the

121 establishment years, but was certified organic in the first cropping year (2008) - a typical

122 scenario for commercial growers. The planting was considered mature in the eighth growing

123 season (2014). There were 48 treatment combinations arranged in a balanced factorial $(2 \times 4 \times 2$

$124 \times 3)$ split-split plot design with five replicates. The main plots were bed configuration (raised

125 beds of $\sim 0.3 \mathrm{~m}$ high or flat ground $)$, the subplots were fertilizer rate and source $(2$ rates $\times 2$

126 sources), and the sub-subplots were cultivar (the early-season 'Duke' and mid-season 'Liberty')

127 and mulch treatment ('compost + sawdust', sawdust, or weed mat). Sub-subplots were $4.6 \mathrm{~m}$

128 long with six plants each. Plant spacing was $0.76 \mathrm{~m}$ by $3 \mathrm{~m}$ (4385 plants/ha). The plants were

129 drip irrigated, and irrigation rate was adjusted to maintain soil water content at similar values

130 across treatments. Details on planting establishment are provided elsewhere (Larco et al., 2013a,

131 2013b). Treatments are briefly described here.

132 Mulch treatments were: a) Douglas fir (Pseudotsuga menziesii M.) sawdust mulch (9 $\mathrm{cm}$

133 deep; $360 \mathrm{~m}^{3} \cdot \mathrm{ha}^{-1}$ ); b) compost (municipal yard debris, $4 \mathrm{~cm}$ deep; $152 \mathrm{~m}^{3} \cdot \mathrm{ha}^{-1}$ ) plus Douglas fir

134 sawdust ( $5 \mathrm{~cm}$ deep; $\left.200 \mathrm{~m}^{3} \cdot \mathrm{ha}^{-1}\right)$ mulch on top (compost + sawdust); and c) weed mat [black,

135 woven polyethylene ground cover (TenCate Protective Fabrics; OBC Northwest Inc., Canby,

136 OR)] with sawdust mulch $(5 \mathrm{~cm})$ in the $20-\mathrm{cm}$ diameter planting hole $\left(1.4 \mathrm{~m}^{3} \cdot \mathrm{ha}^{-1}\right)$. The intent of

137 the compost + sawdust treatment was to have the sawdust mulch act as a barrier to weed seed 
138 germination in the more nutrient-rich compost layer. The two organic mulches were initially

139 applied in 2006 just after planting and were replenished in Jan. 2011 and 2013 as needed to

140 maintain mulch depth. The solid 1.5-m-wide piece of weed mat, centered over the row, was

141 installed just prior to planting and was replaced with "zippered" weed mat (overlapping pieces

142 stapled in place) in the winter of 2010-2011 allowing the weed mat to be opened and granular

143 fertilizers to be applied underneath. The mulches are further characterized for their properties in

144 Sullivan et al. (2015). Weeds were removed by hand-weeding from plots mulched with sawdust

145 and weed mat (i.e., the planting hole area) and were controlled using OMRI-approved (Organic

146 Materials Review Institute) post-emergent acetic acid (20\%; WeedPharm ${ }^{\circledR}$, Pharm Solutions,

147 Inc., Port Townsend, WA), lemon grass oil or d-limonene (GreenMatch EX ${ }^{\circledR}$ and Avenger ${ }^{\circledR}$,

148 respectively, Cutting Edge Formulations, Inc., Buford, GA), and propane flaming in addition to

149 hand-weeding in plots mulched with compost + sawdust. Labor and product costs were recorded

150 (Julian et al., 2012).

151 Fertilizer rate and source treatments were granular feather meal (ranging from $11 \%$ to

$15213 \% \mathrm{~N}$, depending on product or batch) or fish emulsion ( $4 \%$ to $5 \% \mathrm{~N})$ applied initially at "low" 153 and "high" rates of 29 and $57 \mathrm{~kg} \cdot \mathrm{ha}^{-1} \mathrm{~N}$, respectively, during the first few years of establishment 154 (2007-2009) and then increased incrementally as the planting matured to 73 and $140 \mathrm{~kg} \cdot \mathrm{ha}^{-1} \mathrm{~N}$, 155 respectively, by 2013. In 2007-14, feather meal was broadcast on top of the organic mulches or 156 under the weed mat (around plants from 2007-2010 and opened for application to the in-row area 157 from 2011-2014) with half of the total nitrogen (N) applied in March and the other half in May.

158 Fish emulsion was diluted ( 1 part to 10 parts water $\mathrm{v} / \mathrm{v}$ ) and was applied by hand as a drench 159 around the base of the plants in 2007-2009, side-dressed with a sprayer on each side of the row 
160 in 2010, and injected through the drip system (fertigated) in 2011-14 in seven equal applications

161 every 2 weeks from mid-April to early July.

162 From the first (2008) through the eighth (2014) fruiting seasons, ripe fruit were harvested

163 by hand approximately every 7 days. In 2011-2014, the planting was sprayed weekly with a

164 spinosad (metabolites of Saccharopolyspora spinosa) insecticide (Entrust ${ }^{\circledR}$ SC; Dow Agro

165 Science, Indianapolis, IN), from the time when 'Liberty' fruit first turned blue through harvest,

166 to help control Spotted Wing Drosophila [Drosophila suzukii (Matsumura)]; applications to the

167 early-season 'Duke' were not required as insect populations were very low. In 2013-2014, the

168 fungicide Bacillus subtilis (Serenade ${ }^{\circledR}$ MAX; AgraQuest, Davis, CA) was applied in spring for

169 control of gray mold (Botrytis cinerea Pers.) per label rate and recommendations. No other

170 pesticides were required during the study period. Scare alarms (Bird Gard LLC, Sisters, OR)

171 were used for bird control. To determine the returns per treatment, fruit were sold to a

172 commercial organic berry packer (fresh and processed markets). Additional information on data

173 collection is provided in Larco et al. (2013a, 2013b). Analysis of all treatment effects on

174 measured variables was done as a complete factorial for a split-split plot design using the PROC

175 MIXED procedure in SAS software package version 8 (SAS Institute, Cary, NC). Contrasts were

176 used to compare the effect of fertilizer rate and source and compost type on measured variables.

177 Means were separated at the 5\% level using Fisher's protected LSD test.

178 2.1.2. Blueberry, cultivar adaptation

179 Ten cultivars (Duke, Bluecrop, Reka, Bluejay, Bluegold, Draper, Legacy, Liberty,

180 Ozarkblue, and Aurora) were established in October 2006 at the certified organic planting site

181 described above (2.1.1.). Plants were either grown with a) pre-plant amendment (a combination

182 of municipal yard debris compost and Douglas fir sawdust), incorporated prior to forming the 
183 raised beds and planting, topped with a mulch of the same yard debris compost and sawdust or b)

184 no pre-plant amendment, but including a mulch of Douglas fir sawdust topped with weed mat (as 185 described in 2.1.1.). Each experimental unit consisted of a 5-m plot containing seven plants. The

186 experimental design was a balanced split-plot with amendment-mulch treatment as the main plot

187 and cultivar as the split plot with two replicates. Data were collected on yield and fruit quality

188 [berry weight, firmness, and total soluble solids (TSS)] from 2008-2013. In six of the cultivars

189 (Duke, Bluecrop, Draper, Legacy, Liberty, and Aurora) leaves were sampled every 2 weeks

190 throughout the growing season in 2013-2014 to determine changes in tissue nutrient

191 concentration over time. Further information on planting establishment and data collection are

192 provided in Strik and Vance (2015). Analysis of all treatment effects on measured variables was

193 done using the PROC MIXED procedure in SAS software package version 8 (SAS Institute,

194 Cary, NC). Mean comparison was performed using LSMEANS.

195

196

\subsection{Blackberry}

\subsubsection{Blackberry organic systems trials for processing}

198 The 0.4-ha research trial was planted in May 2010 using tissue-cultured plug plants.

199 Plant spacing was $1.5 \mathrm{~m}$ in the row and $3 \mathrm{~m}$ between rows (2222 plants/ha). Weeds around the

200 small plants were removed by hand in the planting year. Any primocanes that grew in 2010 were

201 pruned off to crown height in the following winter such that only primocanes grew in 2011 per

202 standard commercial practice (Harkins et al., 2013; Strik and Finn, 2012). The plants were drip

203 irrigated, and irrigation rate was adjusted to maintain soil water content at similar values across

204 treatments. An OMRI-approved fish hydrolysate and fish emulsion blend was diluted (1 part to

20510 parts water v/v) and applied through the drip system (4\% to $5 \% \mathrm{~N}$, depending on product and 
206 batch). The fertilizer was divided into eight equal applications (approximately every 2 weeks

207 from early April to late-June or early July) and applied at a total rate of $56 \mathrm{~kg} \cdot \mathrm{ha}^{-1} \mathrm{~N}$ in 2010-

2082012 and $90 \mathrm{~kg} \cdot \mathrm{ha}^{-1} \mathrm{~N}$ in 2013-2014 (based on percentage of $\mathrm{N}$ as stated on the label). The

209 planting was certified organic in the first cropping year (2012).

210 There were 24 treatment combinations arranged in a balanced factorial $(2 \times 2 \times 3 \times 2)$

211 split-split-split plot design with five replicates and included a row of 'Marion' and a row of

212 'Black Diamond' blackberry as main plots, two irrigation strategies (postharvest and no

213 postharvest irrigation) as subplots, and a combination of three weed management strategies

214 (weed mat, hand-weeded, and non-weeded) and two primocane training dates (August and

215 February) as sub-subplots. Each sub-subplot consisted of four plants and was separated from

216 plants in adjacent plots by $3.0 \mathrm{~m}$ to provide space for clearing the machine harvester. Treatments

217 are briefly described here but more information is provided by Dixon et al. (2015). Data were

218 analyzed using PROC GLM in SAS (SAS Institute Inc., Cary, NC), and means were separated at

219 the 5\% level using Fisher's protected LSD test.

220 The three weed management treatments were: 1) "non-weeded" where weeds were not

221 removed from 2011-2014, but were cut to soil level just prior to machine harvest (early July) to

222 avoid any interference with the catcher plates; 2) "hand-weeded" where weeds were removed by

223 hand hoeing on three to four dates per year (2010-2014); and c) "weed mat" where plots were

224 covered in a 1.4-m-wide strip of black, woven polyethylene ground cover (TenCate Protective

225 Fabrics; OBC Northwest Inc., Canby, OR) centered on the row just prior to planting; openings

226 were cut for each plant, creating a planting hole. Weeds were removed from the planting hole

227 area and seams in the weed mat, as required annually. 
229 Fresno, $\mathrm{CA} ; 1.9 \mathrm{~L} \cdot \mathrm{h}^{-1}$ in-line every $0.6 \mathrm{~m}$ ), placed along the ground at the base of the plants

230 under the weed mat or attached to a trellis wire at $0.3 \mathrm{~m}$ above the ground in the non-weeded and

231 hand-weeded plots. The cultivar, irrigation, and weed management treatment combinations were

232 irrigated independently based on estimates of crop evapotranspiration (ET), plant water status,

233 and soil water content (Dixon et al., 2015). Irrigation was applied in the postharvest irrigation

234 treatment the entire dry season from early May through late-September to early October in 2012-

235 2014. In the "no postharvest irrigation" treatment, irrigation was initiated on the same dates in

236 spring but withheld after the last fruit harvest (in mid- to late-July 2012-2014). Thus the latter

237 plots received no additional water until the rainy season began in late September to early October 238 depending on the year.

239 Primocanes in the August-trained treatment were trained to two upper trellis wires (at 1.0

$240 \mathrm{~m}$ and $1.6 \mathrm{~m}$ ) in mid- to late August of 2012-2014, after pruning out the senescent floricanes,

241 using the method described by Dixon et al. (2015). In the February-trained treatment, primocanes

242 were left in a bundle near the ground throughout the growing season and subsequent winter until

243 they were trained to the upper trellis wires in late February 2013-2014.

244 In 2012-2013, the efficacy of fertigation with an OMRI-approved fish hydrolysate and

245 fish emulsion blend (TRUE 402; 4N-0P-1.7K; True Organic Products, Inc., Spreckels, CA) and

246 a natural microbial digestion of corn steep liquor and ground fish waste (AgroThrive $2.5 \mathrm{~N}-1.1 \mathrm{P}-$

247 1.2K; AgroThrive, Inc., Morgan Hill, CA) was evaluated based on drip emitter performance with

248 or without flushing of the system (Fernandez-Salvador et al., 2015a). Additional information on

249 fertilization and planting maintenance can be found in Harkins et al. (2014, 2013), Dixon et al.

250 (2015) and Fernandez-Salvador (2015a). Data were analyzed using PROC GLM in SAS (SAS 
251 Institute Inc., Cary, NC), and means were separated at the 5\% level using Fisher's protected LSD 252 test.

Ripe fruit were harvested twice weekly from late June to mid-July (2012-2014), using an

254 over-the-row rotary machine harvester (Littau Harvesters Inc., Stayton, OR). Data were collected 255 on yield, berry weight, percent fruit moisture and TSS as well as plant growth and biomass

256 (Dixon et al., 2015; Fernandez-Salvador et al., 2015a; Harkins et al., 2013).

\subsubsection{Blackberry organic trials for fresh market}

Four trailing blackberry cultivars (Obsidian, Black Diamond, Metolius, Onyx) and two

259 advanced selections (ORUS 1939-4 and ORUS 2635-1) were evaluated from 2010-2013 in a

260 certified organic blackberry planting at the North Willamette Research and Extension Center,

261 described above in 2.2.1. Plants were irrigated using a drip line under a woven polyethylene

262 ground cover (weed mat) installed for weed management. Liquid fertilizers injected through the

263 drip system were used at a rates of $56 \mathrm{~kg} \cdot \mathrm{ha}^{-1} \mathrm{~N}$ in $2010-2012$ and $90 \mathrm{~kg} \cdot \mathrm{ha}^{-1} \mathrm{~N}$ in 2013 . Fruit

264 were hand harvested in 2012 and 2013, the first and second fruiting seasons, respectively. The

265 study was arranged as a balanced randomized complete block design with four replicates each of

266 the six blackberry genotypes. Plant spacing was $1.5 \mathrm{~m}$ in the row and $3 \mathrm{~m}$ between rows ( 2222

267 plants/ha). Data were collected on plant growth, yield, and fruit quality. More information on

268 planting establishment, maintenance and data collection may be found in Fernandez-Salvador et

269 al. (2015c). Data were analyzed using PROC GLM in SAS (SAS Institute Inc., Cary, NC), and

270 means were separated at the 5\% level using Fisher's protected LSD test.

271 A separate trial was conducted from 2011-2012 at a certified organic site of a grower-

272 collaborator located in Jefferson, OR. Three trailing blackberry cultivars (Marion, Black

273 Diamond, and Obsidian) and one semi-erect cultivar (Triple Crown) were studied for their 
274 response to different types of fertilizer from 2011-12. Plants were drip irrigated, and weeds were

275 managed using a polypropylene, permeable landscape fabric (weed mat). All cultivars were

276 fertilized at a target rate of $56 \mathrm{~kg} \cdot \mathrm{ha}^{-1} \mathrm{~N}$ in spring 2011 and 2012 using three different sources: 1)

277 a liquid fish and molasses blend (“TRUE 402"; 4N-0P-1.7K; True Organics, Spreckels, CA); 2)

278 pelletized soy (Glycine max) meal (8N-0.4P-1.7K; Phyta-Grow ${ }^{\circledR}$ Leafy Green Special ${ }^{\mathrm{TM}}$;

279 California Organic Fertilizers, Hanford, CA); and 3) pelletized, processed poultry litter (4N-

280 1.3P-2.5K-7Ca; Nutri-Rich ${ }^{\circledR}$, Stutzman Environmental Products, Canby, OR). All fertilizers

281 were applied under the weed mat (by opening, applying the product and then re-closing the weed

282 mat). The fish fertilizer was diluted (1 part to 10 parts water v/v) prior to applying in four equal

283 portions from late April to early June. The granular soy meal and poultry litter were applied in

284 late April.

285 Treatments were arranged in a balanced split-plot design with three replicates and

286 included the four cultivars as main plots and three fertilizer sources as subplots (Fernandez-

287 Salvador et al., 2015b) for more information. Data were analyzed using PROC GLM in SAS

288 (SAS Institute Inc., Cary, NC), and means were separated at the 5\% level using Fisher's

289 protected LSD test.

290

291 3. Key results and discussion

292

\section{3.1 Bed configuration in blueberry}

294 Blueberry plants may be grown on flat ground or on raised beds, which improve drainage

295 and soil aeration thus reducing the incidence of root rot (Bryla and Linderman, 2007; Bryla et al.,

296 2008) and improve root growth (Larco et al., 2013a). Raised beds also increase machine-harvest 
297 efficiency (Strik and Buller, 2002). Prior to our study, there had been no long-term comparison

298 of flat ground to raised-bed production and we hypothesized that mechanical methods of weed

299 control might be possible in flat ground production (Sciarappa et al., 2008) that were not possible

300 with raised beds. However, we quickly observed that during establishment (the first 2 years),

301 blueberry plants grown on raised beds produced 33\% higher yields than those on flat ground

302 (Larco et al., 2013a), warranting the added establishment costs and leading to greater economic

303 returns (Julian et al., 2012). In addition, cumulative yield per plant (2008-2014) averaged 21\%

304 higher on raised beds than on flat ground, likely due to increased root growth (Valenzuela-

305 Estrada et al., 2011b). The majority of blueberry growers in this region now establish blueberry

306 fields on raised beds.

307

3.2 Impacts of weed management systems on yield, quality, and costs

\subsubsection{Blueberry}

For the weed management strategies evaluated in the organic blueberry production

311 systems trial, we used various methods to control weeds, because judicious weed control is

312 critical for good growth and yield in blueberry (Krewer et al., 2009). We found an effect of

313 mulch type on yield, despite weeds being controlled in all treatments. In the first fruiting year

314 (2008), yield per plant was highest with weed mat and lowest with sawdust mulch (Larco et al.,

315 2013a). Plants grown on weed mat had a higher shoot-to-root ratio (Larco et al., 2013a) perhaps

316 a result of higher soil temperatures measured under weed mat than under the sawdust mulches

317 (Larco, 2010; Valenzuela-Estrada et al., 2011a). However, more irrigation water was required in

318 the weed mat mulch, relative to the organic mulches, particularly for plants grown on raised beds

319 during establishment (Larco, 2010) and through maturation (Strik et al., unpublished). There was 
no significant main effect of mulch (averaged over planting method, cultivar, fertilizer source

321 and rate) on cumulative yield per hectare (2008-2014), but the contrast comparing weed mat to

322 the organic mulches (sawdust and compost + sawdust) indicated the $4 \%$ greater yield for weed

323 mat was significant $(P<0.05)$. There were also some interaction effects of mulch when the

324 cultivars were grown on raised beds and fertilizer source was considered (3.4.1).

325 When plants were young, berry weight was lower when 'Duke' was grown with weed

326 mat compared to the organic mulches. However, the opposite was found in 'Liberty' (Larco et

327 al., 2013a). While weed mat did reduce average berry weight over the seven fruiting seasons, the

328 range of $2.19 \mathrm{~g}$ (weed mat) to $2.23 \mathrm{~g}$ (sawdust) found was not commercially relevant (data not

329 shown). Mulch type had no consistent effect on fruit firmness or TSS through the study period

330 and no average effect over the 7 years (data not shown). In Georgia, rabbiteye blueberry ( $V$.

331 virgatum Ait.) established with organic mulches had a similar yield to those with weed mat in the

332 first 2 years of establishment, but higher yields in years 3 - 5 (Krewer et al., 2009).

333 More weeds were found in the compost + sawdust mulch than the sawdust mulch alone

334 throughout the study period (Julian et al., 2012) as also reported by others in blueberry

335 (Burkhard et al., 2009). While the compost was initially free of weed seeds, the upper layer of

336 dry sawdust eroded through wind and hand-pulling of weeds, thus bringing the nutrient rich,

337 moist compost to the surface. Weed seeds that blew into the planting appeared to germinate

338 readily in this compost layer.

339 In certified organic systems, chemical options for weed control are limited to directed

340 applications of acetic acid (20\% vinegar), lemon grass oil or d-limonene, and hand removal. The

341 approved organic burn-down herbicides performed poorly on established weeds in our study

342 (Larco, 2010; Julian et al., 2012) and others in Georgia (Tertuliano et al., 2012). Propane flaming 
343 worked reasonably well on smaller weeds (Julian et al., 2012; Larco, 2010), but may damage the 344 crop plant (Granatstein and Mullinix, 2008) or be a fire hazard in plantings mulched with organic 345 materials such as sawdust. We found almost complete weed control with weed mat in the row 346 although weeds did appear in the cut planting hole area thus requiring hand removal (Julian et 347 al., 2012; Larco, 2010). Sciarappa et al. (2008) also found almost complete control of weeds 348 when using weed mat plus a mulch of coffee grounds around the planting hole in organic 349 blueberry in New Jersey, USA.

350 In an economic analysis of the weed management strategies studied, we noted the costs 351 of installation (product and labor) were $\$$ US3065/ha, $\$ 4497 /$ ha, and $\$ 5652 /$ ha for the weed mat 352 (when amortized over 5 years), sawdust, and compost + sawdust mulches, respectively (Julian et 353 al., 2012). Cumulative net returns for 2006 (planting establishment) through 2009 (second 354 fruiting season) averaged $-\$ 36,874$ for weed mat, $-\$ 41,568$ for sawdust, and $-\$ 44,068$ per 355 hectare for compost + sawdust (net loss during establishment years); losses were greater for 356 compost + sawdust due to the high weed management costs associated with this mulching 357 strategy (Julian et al., 2012).

358 Weed mat has become very common in organic as well as conventional blueberry fields 359 in the Pacific northwestern United States, thus reducing costs of herbicides and hand weeding. 360 The costs of producing organic and conventional blueberry were estimated by Julian et al.

361 (2011a, 2011b). The cash costs to establish a new planting of conventional blueberry can surpass 362 \$US30,165/ha and result in return of -\$9995/ha (a net loss) during the first 6 years (Julian et al., 363 2011a). In contrast, the cash costs required to establish a "typical" organic blueberry field were 364 higher at $\$ 32,520 /$ ha, but the net return through year 6 was $\$ 6,930 /$ ha (Julian et al., 2011b). In 365 plantings yielding $18 \mathrm{t} \cdot \mathrm{ha}^{-1}$ per year, the break-even price (to cover total costs for the year) was 
estimated to be $\$ 3.08 / \mathrm{kg}$ for organic blueberries produced in Oregon (Julian et al., 2011b) and

$367 \$ 10 / \mathrm{kg}$ in southern California (Takele et al., 2007). In Georgia, net returns were estimated to be

368 higher for organic than conventional rabbiteye production over a 6-year period despite a lower

369 yield in organic plots (Tertuliano et al., 2012). However, net returns are impacted greatly by the

370 production system used, yield, and fruit prices (Julian et al., 2012).

\subsubsection{Blackberry}

The possibility of ceasing irrigation of blackberry plants after harvest in our dry summers

373 (for August and September) was appealing as this would aid in weed control. Some blackberry

374 growers in Oregon do not irrigate at all and some use this practice to try to increase winter cold

375 hardiness, especially in the cold-sensitive cultivar Marion (Bell et al., 1995, 1992). In our trial,

376 we found no effect of deficit irrigation after fruit harvest on yield, saving an estimated 1 million

$377 \mathrm{~L} \cdot \mathrm{ha}^{-1}$ over the 2 years of the study (Dixon et al., 2015). In addition, 'Marion' plants that were

378 deficit irrigated had less cold damage than those that received irrigation all summer (Dixon et al.,

379 2015). 'Marion' plants also had more cold injury when grown in non- and hand-weeded plots

380 and when trained in August versus February. However, when weed mat was used as a mulch,

381 training in February resulted in greater cold injury perhaps because the canes were more

382 vigorous, delaying acclimation relative to those in weedy plots (Dixon et al., 2015). August

383 training has been shown to increase risk of cold injury in grower fields in susceptible cultivars

384 (Bell et al., 1992).

385 In non-weeded plots, the tall weeds did not interfere with machine harvesting as they

386 were cut to soil level just prior to harvest using a scythe. There were no obvious treatment effects

387 on the presence or absence of insect harvest contaminants. 
Trailing blackberry plants grown with weed mat were more vigorous than those grown in

389 hand-weeded (bare soil) plots and with no weed control producing $25 \%$ and $100 \%$ higher yields,

390 respectively (Dixon and Strik, 2015). There was an interaction between cultivar and weed

391 management strategy on cumulative machine-harvested yield (2012-2014), mainly because there

392 was a greater positive effect of weed control on yield of 'Black Diamond' than of 'Marion' (Fig.

393 1A). Also, 'Black Diamond' had a higher yield when grown with weed mat than when hand-

394 weeded, whereas there was no difference between these weed control methods in 'Marion'. In

395 addition, weed control (either by hand-weeding or weed mat) increased average berry weight

396 (5.65 g versus 5.20 g) and fruit water content (data not shown), but reduced fruit TSS in 'Black

397 Diamond' (Fig. 1B). The latter is likely a function of concentration compared to the non-weeded

398 plots (Dixon et al., 2015; Harkins et al., 2013). The reason for the higher yield with weed mat

399 than bare soil in 'Black Diamond' is not known at this time. It is possible, that the small weeds

400 that were present prior to hoeing may still have competed with the blackberry plants and 'Black

401 Diamond' and 'Marion' may differ in root system architecture or ability to access soil water

402 (Valenzuela-Estrada et al., unpublished). While there was little effect of weed mat on soil

403 temperature, this mulch may have influenced root growth (data not shown). It is possible that

404 plants in the non-weeded plots could have benefitted from additional fertilizer applications

405 relative to those in the weed-controlled plots. However, based on measurements of plant water

406 status and soil water content, plants were not stressed for water (data not shown). It is clear that

407 judicious weed control is needed to maximize yield in blackberry, as has been confirmed by

408 others (Makus, 2011; Meyers et al., 2014).

409 Weed mat required a high initial investment to install (Harkins et al., 2013), but only 16

$410 \mathrm{~h} \cdot \mathrm{ha}^{-1}$ of labor to maintain over the 5-year study period (Dixon and Strik, 2015). The non-weeded 
411 and hand-weeded treatments required 25 and $215 \mathrm{~h} \cdot \mathrm{ha}^{-1}$ of labor to mow tall weeds prior to

412 harvest and hand hoe, respectively. Total cumulative costs, including materials and installation

413 (weed mat) over the 5 years were $\$ 3302 /$ ha for weed mat, $\$ 3231 /$ ha for hand weeding, and

$414 \$ 370 /$ ha for no weeding (labor was valued at $\$ U S 15 / h$ ). However, when cumulative yield and

415 returns were factored in, the hand-weeded and weed mat management strategies increased net

416 returns by $40 \%$ and $71 \%$ compared to non-weeded plots, respectively. In addition, weed mat had

417 a $22 \%$ higher cumulative net return than the hand-weeded treatment (Dixon and Strik, 2015). It

418 is clear from our studies to date that organic growers should seriously consider using weed mat

419 for weed management in machine-harvested organic trailing blackberry.

4213.3 Impacts of weed management systems on soil and plant nutrients

$422 \quad$ 3.3.1 Blueberry

423 We analysed the organic mulch materials used in our organic research trials for nutrient

424 content (Table 1). The municipal yard debris compost was added as a component of one of the

425 mulch treatments because of hypothesized organic matter, nutrient, microbiological benefits

426 (e.g., Forge et al., 2003), and a low soluble salt (EC), as blueberry plants are sensitive to high

427 levels of salt (Larco et al., 2014). Yard debris compost is produced by Oregon municipal

428 composting programs and typically costs 1.5 to 2 times more than sawdust. While we have not

429 yet measured impacts of mulches on soil microbiology, we have noted differences in soil

430 properties and nutrients. Because organic sources of $\mathrm{N}$ are expensive and often laborious to

431 apply, the potential for a slow-release $\mathrm{N}$ benefit from compost is of great economic significance.

432 The slow-release $\mathrm{N}$ provided by the yard debris compost was estimated at roughly $25 \mathrm{~kg} \cdot \mathrm{ha}^{-1} \cdot \mathrm{yr}^{-1}$ 
433 (3\% of total compost-N applied), based on experience with similar composts applied before 434 planting in grass (Sullivan et al., 2003) and sweet corn (Gale et al., 2006).

436 contributed few nutrients to the soil during the study period (Table 1). In contrast, the yard debris

437 compost contained high $\mathrm{N}, \mathrm{P}, \mathrm{K}, \mathrm{Ca}$, and $\mathrm{Mg}$ and with the low $\mathrm{C}: \mathrm{N}$ ratio (24) was likely a 438 significant contributor to soil and/or plant nutrient status (Sullivan et al., 2015). Although compost supplied a high rate of total $\mathrm{N}$, estimated at $25 \mathrm{~kg} \cdot \mathrm{ha}^{-1} \mathrm{~N}$ per year of 440 the study, it apparently supplied low amounts of plant-available N. The addition of compost to 441 the mulch had no effect on blueberry leaf N concentration in 2007-2008 (Larco et al., 2014, 442 2013b), but did increase leaf $\mathrm{N}$ compared to sawdust alone in 2009 and 2013 (data not shown).

443 Leaf $\mathrm{N}$ concentrations, on the other hand, were below published sufficiency levels (1.76-2.0\%;

444 Hart et al., 2006b) in all treatments in 2012-2014, despite reaching commercially acceptable 445 yields of $10-18 \mathrm{t} \cdot \mathrm{ha}^{-1}$.

446 Compost contained $5.6 \mathrm{~g} \cdot \mathrm{kg}^{-1} \mathrm{~K}$ on a dry-weight basis compared to $0.05 \mathrm{~g} \cdot \mathrm{kg}^{-1} \mathrm{~K}$ for 447 sawdust (Larco et al., 2014), leading to a $60 \%$ increase in soil K compared to sawdust alone by 448 the sixth year (Sullivan et al., 2015). Leaf K concentration was higher in 5 of 7 years when 449 compost was added to the mulch compared to sawdust alone (data not shown). Our previous 450 research demonstrated a potential long-term problem with too much $\mathrm{K}$ in compost (Costello, 4512011 ) and high soil $\mathrm{K}$ has been observed to induce Mg deficiency in blueberry plants (Eck, 1988; 452 Krewer and Ruter, 2012).

453 Addition of compost in the mulch increased soil $\mathrm{Ca}, \mathrm{Mg}$, and $\mathrm{pH}$ relative to the sawdust 454 mulch alone. However, differences in soil nutrient levels were not always reflected in leaf 455 nutrient concentrations (Sullivan et al., 2015). Adding compost to the mulch also increased soil 
organic matter, averaging $3.9 \%$ compared to $3.3 \%$ with sawdust alone. In contrast, soil organic

457 matter under the weed mat was significantly lower averaging 3.1\%. Weed mat also increased soil

458 nitrate- and ammonium-N $\left(\mathrm{NH}_{4}-\mathrm{N}\right), \mathrm{Ca}$, and $\mathrm{Mg}$ in autumn, compared to sawdust mulch alone

459 (Larco et al., 2013b; Sullivan et al., 2015) likely a result of a reduction in soil nutrients at the

460 sampling depth from leaching with rainfall. Soil $\mathrm{pH}$ remained within the recommended range for

461 blueberry (4.5 to 5.5; Hart et al., 2006b) during the course of the study for all mulches, and the

462 use of a high-pH compost (e.g. pH 7 for the mulch used) as part of a mulching program may help

463 mitigate the decline in soil $\mathrm{pH}$ that occurs with long-term fertilization. We continue to evaluate

464 whether sustained compost use as part of a fertilization and mulching program may adversely

465 affect soil and blueberry plant health.

466 While including a high-pH compost as part of a mulching program may be of benefit, we

467 found that incorporating a yard debris compost ( $\mathrm{pH}$ of $7.5 ; \mathrm{EC} 0.7 \mathrm{dS} \cdot \mathrm{m}^{-1}$ ) prior to planting

468 followed by adding a small amount of the same compost to the surface mulch increased soil $\mathrm{pH}$

469 significantly compared to no pre-plant amendment and sawdust topped with weed mat as a

470 mulch. Soil pH was 6.2 and above the recommended range for blueberry (Hart et al., 2006b) in

471 the amended plots compared to 5.3 in the weed mat mulched plots, leading to differences in plant

472 leaf nutrient concentration, growth, and yield from establishment through plant maturity (Strik

473 and Vance, 2015).

\subsubsection{Blackberry}

475 In organic trailing blackberry, the use of weed mat as an in-row mulch increased soil K,

$476 \mathrm{Mg}, \mathrm{Mn}$, and Al when measured in autumn of each of the study years (2012-2014) and increased

477 soil $\mathrm{Ca}, \mathrm{NH}_{4}-\mathrm{N}, \mathrm{pH}$, and organic matter content in 2013 and 2014 compared to the hand-weeded

478 or bare soil treatment (Dixon et al., unpublished; Harkins, 2013). The increased organic matter 
479 content under the weed mat is in contrast to what we found in blueberry, when compared to 480 sawdust mulch (Strik et al., unpublished; Sullivan et al., 2015), and others have found in apple 481 (Malus $\times$ domestica Borkh.) (Choi et al., 2011) and may have been a result of greater root growth 482 in the sampled region in weed mat than in the bare soil treatment (Valenzuela-Estrada et al., 483 unpublished). In blackberry, as much as $84 \mathrm{~kg} \cdot \mathrm{ha}^{-1} \mathrm{~K}$ is removed from the plant in harvested fruit 484 and pruned floricanes, and removal of $\mathrm{K}$ was $41 \%$ and $24 \%$ greater in weed mat than in the non485 and hand-weeded treatments, respectively (Harkins et al., 2014). Despite the greater losses with 486 weed mat, the soil $\mathrm{K}$ level was still higher than in the hand-weeded plots. Other than higher Al 487 concentration in primocanes, there was no consistent effect of soil nutrient content on primocane 488 leaf nutrient concentration (Dixon et al., unpublished; Harkins et al., 2014). Weed mat did 489 increase fruit $\mathrm{Ca}$ concentration $(0.21 \%)$ compared to hand-weeded and non-weeded $(0.19 \%)$ 490 treatments (Harkins et al., 2014).

\subsection{Impacts of fertilizer source}

493 We analysed all of the organic fertilizers used in our research trials for nutrient content

494 (Table 1). Even though all of the fertilizers were applied at a similar target rate of nitrogen 495 (based on the percentage of $\mathrm{N}$ as stated on the product label), there were still differences in the 496 actual rate of $\mathrm{N}$ applied because the nutrient concentration in the product did not exactly match 497 the stated concentration on the label. In addition to N, most of the organic fertilizers studied also 498 contained high amounts of $\mathrm{P}$ (poultry litter, grain fermentation, and corn steep liquor), K (poultry 499 litter, fish emulsion, grain fermentation, and corn steep liquor) and Ca and $\mathrm{Mg}$ (poultry litter).

500 The impacts of addition of these nutrients when using organic fertilizer materials or products, 
501 even when they are not required by the plants, must be considered in these organic production 502 systems.

503 The available fertilizer sources differed in cost of application. For example, feather meal, 504 soy meal and other pelletized products are applied as granular products on top of the organic 505 mulch or under the weed mat, whereas fish emulsion and other liquid blends may be fertigated

506 (Fernandez-Salvador et al., 2015a). However, these products also differ greatly in cost per unit of $507 \mathrm{~N}$, ranging from $\$$ US5.60/kg for the pelletized, processed poultry litter, $\$ 10.00 / \mathrm{kg}$ for the feather 508 meal, $\$ 11.77 / \mathrm{kg}$ for the soy meal, and $\$ 17.95 / \mathrm{kg}$ for the fish blends (Fernandez-Salvador et al., 509 2015b; Julian et al., 2012; Larco et al., 2014).

\subsubsection{Blueberry}

511 Nitrogen is the predominant nutrient routinely applied to blueberry, and the best growth 512 and yield is usually achieved with $25-100 \mathrm{~kg} \cdot \mathrm{ha}^{-1} \mathrm{~N}$ in conventional as well as organic systems

513 (e.g., Bañados et al., 2012; Cummings et al., 1971; Eck, 1988; Hanson, 2006; Hart et al., 2006b).

514 The most common OMRI-approved products used as nitrogen sources in organic blueberry are

515 fish emulsion or feather meal. Nitrogen uptake increases throughout the growing season in young

516 plants but primarily occurs during shoot and early fruit development in the spring in mature

517 plants (Bañados et al., 2012; Retamales and Hanson, 1989; Throop and Hanson, 1997). The

518 current recommendation is to apply $\mathrm{N}$ in split applications in the spring when using granular

519 fertilizers (April to June; Hart et al., 2006b) or to fertigate with frequent applications of low rates

520 of $\mathrm{N}$ from spring to midsummer when using liquid fertilizers (Bryla and Machado, 2011).

521 However, organic farmers commonly apply liquid fish emulsion to the soil directly, especially in 522 young plantings. Granular feather meal and grain-based products are also commonly applied 523 directly to the in-row area, after opening the weed mat, if present. 
The rates of $\mathrm{N}$ and other macro- and micronutrients applied to blueberry are routinely

525 adjusted based on leaf tissue analysis. While the patterns of nutrient changes in sampled leaves

526 over the growing season were similar among conventional- and organically-managed blueberry

527 cultivars, Strik and Vance (2015) speculated that tissue nutrient standards may need to be

528 adjusted for some nutrients when plants are grown in organic systems.

529 We have observed cultivar differences in plant growth and yield response to fertilizer

530 source and rate during establishment and maturation in blueberry. When plants were

531 establishing, fish emulsion increased growth compared to feather meal, likely because $\mathrm{N}$ in the

532 fish was more available to plants when needed (Larco et al., 2013b; Valenzuela-Estrada et al.,

533 unpublished). In later years, when the first application of feather meal was made earlier to

534 improve $\mathrm{N}$ availability, there was little effect of fertilizer source and rate in 'Liberty', on

535 average, whereas 'Duke' had higher yields when fertilized with feather meal than with fish

536 emulsion. When we began our research, the most common production system used in organic

537 fields was growing blueberry on raised beds, mulching with sawdust and fertilizing with the

538 higher rate of fish emulsion. When we compared cumulative yield in our study to this industry

539 standard, there was no significant effect of any other mulching or fertilizer source treatment on

540 yield of 'Liberty' (Fig. 2). However, in 'Duke' use of feather meal increased yield in all mulch

541 types compared to when fish emulsion was used as the fertilizer source.

542 In 'Duke', fertilization with the low rate of fish emulsion led to greater cumulative yield

543 than with the high rate of fish emulsion (data not shown). High rates of fertilizer, particularly of

544 fish emulsion, have reduced soil pH over time (Strik et al., unpublished), which is a concern

545 because soil pH management is critical in blueberry (Hart et al., 2006b). 
Nitrogen is the predominant nutrient routinely applied to blackberry, and the best growth

548 and yield is usually achieved with $28-56 \mathrm{~kg} \cdot \mathrm{ha}^{-1} \mathrm{~N}$ during the establishment year and $45-84$

$549 \mathrm{~kg} \cdot \mathrm{ha}^{-1} \mathrm{~N}$ during subsequent years in conventional and organic systems (Bushway et al., 2008;

550 Hart et al., 2006a; Kuepper et al., 2003). The most common OMRI-listed fertilizers applied to

551 organic blackberry are fish emulsion, pelletized chicken litter, soybean meal, and feather meal

552 (Table 1). In blackberry, $\mathrm{N}$ must be available in early spring for sufficient primocane growth

553 (Malik et al., 1991; Mohadjer et al., 2001; Naraguma and Clark, 1998). The current

554 recommendation is to divide the total recommended rate of $\mathrm{N}$ into equal, "split" applications,

555 generally from April through June (Hart et al., 2006a).

556 In trailing blackberry grown for processing, we evaluated two sources of organically-

557 approved liquid fertilizer - a corn steep liquor and fish waste digestion as well as a fish solubles

558 and molasses blend (Table 1; Fernandez-Salvador et al., 2015a). While 'Marion' and 'Black

559 Diamond' differed in plant growth and yield during the study, there was little effect of fertilizer

560 source on plant performance. Primocane leaf tissue nutrient concentrations were within

561 recommended levels for all nutrients, except for a low $\mathrm{Ca}$ and $\mathrm{B}$, and primocane leaf $\mathrm{K}$ and $\mathrm{Zn}$

562 were greater with fish emulsion than with corn as the fertilizer source, likely a result of the

563 higher rate of $\mathrm{K}$ and $\mathrm{Zn}$ applied with fish emulsion (Table 1). When pelletized, processed poultry

564 litter, soybean meal, and fish emulsion were compared at an organic, grower-collaborator site, no

565 differences in the performance of 'Obsidian', 'Marion', 'Black Diamond', and 'Triple Crown'

566 blackberry cultivars were noted (Fernandez-Salvador et al., 2015b).

567 A liquid fish emulsion was successfully used to establish the organic blackberry planting

568 from 2011-2013 (Harkins et al., 2013) and during maturation (Dixon et al., 2015) with no noted

569 adverse effects on drip system emitter performance. While Fernandez-Salvador et al. (2015a) 
570 noted no difference among fertigated corn- and fish-based liquid fertilizers on emitter flow rate

571 of the drip system during the 2 years of study, the flow rates did decline an average of $4.5 \%$ in

572 the first year and 19\% in the second year. It is clear that judicious cleaning of the drip system in

573 spring and fall would be necessary to try to maintain performance over the life of the irrigation

574 system for efficient irrigation and fertigation.

575

\subsection{Cultivar adaptation}

\subsubsection{Blueberry}

A wide range of cultivars are grown in this region for the fresh and processed markets

579 (Strik et al., 2014). When evaluating ten northern highbush blueberry cultivars in two certified

580 organic production systems, all cultivars responded well from establishment through maturation,

581 but cultivars differed in their apparent tolerance to the higher soil $\mathrm{pH}$ resulting from yard debris

582 compost as a pre-plant amendment and as part of the mulching program (see 3.3.1). For example,

583 'Aurora', 'Bluejay', 'Duke', 'Legacy', and 'Ozarkblue' had lower yield when yard debris

584 compost was incorporated prior to planting (compared to no pre-plant amendment), likely due to

585 the higher soil $\mathrm{pH}$ (6.2). In contrast, 'Bluecrop', 'Bluegold', 'Draper', 'Liberty', and 'Reka' did

586 not differ in yield between these planting systems. It is clear that maintaining soil $\mathrm{pH}$ within the

587 current recommended standard of 4.5 to 5.5 is important for many cultivars for optimal growth

588 and production (Hart et al., 2006b; Strik and Vance, unpublished). Cultivars also differed in their

589 growth and yield response to fertilizer source in our trials (see 3.4.1). The differences among

590 cultivars in the measured fruit quality parameters were similar to what has been observed in

591 conventional production systems (data not shown). In southern highbush blueberry, fruit from

592 plants fertilized with 11 different organic fertilizer treatments within the same field showed little 
593 difference in post-harvest fruit quality parameters as compared to unfertilized and conventionally

594 fertilized plants (Echeverría et al., 2009). In contrast, Wang et al. (2008) reported that 'Bluecrop'

595 fruit harvested from different organic blueberry farms had higher TSS, malic acid, total

596 phenolics, total anthocyanins, and antioxidant activity (ORAC) than fruit from conventionally

597 managed farms. In contrast, rabbiteye cultivars differed in total phenolics, anthocyanins, and

598 ORAC values, but no consistent difference between organic and conventional production

599 systems was found (You et al., 2011).

$600 \quad 3.5 .2$ Blackberry

601 Trailing blackberry cultivars are predominantly grown for machine-harvested processed

602 markets in Oregon, but some are also hand-picked for the fresh market. In addition to a few

603 trailing cultivars, erect and semi-erect cultivars are also grown to extend the fresh market fruiting

604 season in Oregon (Finn and Strik, 2014, 2012).

605 In an evaluation of trailing cultivars at the North Willamette Research and Extension

606 Center and of trailing and semi-erect cultivars at a grower collaborator site all cultivars

607 responded well (based on yield and plant growth) to the organic production systems used, with

608 the exception of 'Onyx' and 'Metolius', which were considered to have a low yield for

609 commercial production (Fernandez-Salvador et al., 2015b, 2015c). Within the higher yielding

610 genotypes, 'Obsidian' and ORUS 2635-1 appeared to be the best suited for fresh-market organic

611 production due to their greater fruit size, firmness, sugar to acid ratio, low percent moisture loss

612 (ORUS 2635-1), and a longer number of days of marketable storage ('Obsidian') (Fernandez-

613 Salvador et al., 2015c). 'Obsidian' and 'Triple Crown' fruit were sensitive to gray mold (Botrytis

614 cinerea) and sun burn, respectively, depending on the year and weather (Fernandez-Salvador et

615 al., 2015b), as has been observed in conventional production. 
617 grown in various organic production systems, an infestation of raspberry crown borer [Pennisetia

618 marginata (Harris)] was observed and treatment effects noted (Dixon et al, 2015). The larvae of

619 this insect bore into and damage lower canes and the crown of raspberry (Rubus idaeus L.) and

620 blackberry plants. Symptoms of infestation were evident during training in August where

621 affected primocanes were wilted or "flagging" at the cane tip. These canes broke at the crown

622 easily. In organic production, where options for pest control are limited, the recommended

623 control method for raspberry crown borer is removing and burning infested plants (DeFrancesco

624 et al., 2015). A sex pheromone component for raspberry crown borer has recently been

625 developed and was successful in capturing males in wing traps (Judd et al., 2012; Teasdale et al.,

626 2013). In our study, wing traps with the pheromone bait (Evergreen Growers Supply, Clackamas,

627 OR) were deployed during the second year, as per the recommendations by Teasdale et al.

628 (2013). However, no adult crown borers were captured, despite the presence of the larvae in the

629 field (Dixon et al., 2015). While cultivar differences in susceptibility to this insect pest have not

630 been noted in red raspberry (Breakey, 1963), we found that 'Black Diamond' was affected by

631 this insect in 2013-2014, while 'Marion' was not (Dixon et al., 2015). It is possible that the

632 thornless canes and dark green foliage found in 'Black Diamond' are more attractive to the pest

633 than the thorny canes and lighter green leaves found in 'Marion'.

\section{4. Conclusions}

636 Certified organic research trials over 5 and 8 years in blackberry and blueberry,

637 respectively, affirmed that these crops may be successfully grown in long-term systems for 
638 processed or fresh markets, but the production system can greatly affect plant growth, yield, and 639 economic returns.

640 The various mulches tested for weed control in blueberry resulted in relatively little

641 difference in yield or fruit quality over the 8-year study. However, mulch type impacted weed

642 control costs, root growth and soil and plant nutrient status. Weeds became more prevalent in the

643 mulch that included yard debris compost, thus increasing hand removal costs because the

644 organically-approved herbicides were of limited effectiveness. Mechanical methods of weed

645 control would not be effective in plantings on raised beds which were shown to produce a

646 significantly higher yield than plantings on flat ground. Use of weed mat as a barrier to weeds

647 was the most cost effective weed management strategy in our study.

648 Weed mat led to increased soil temperature and an increase in the shoot-to-root ratio of

649 blueberry plants during establishment relative to sawdust mulch; we are currently assessing the

650 impact of these mulches on biomass allocation in mature plants. More irrigation was required to

651 maintain the same soil water content when weed mat was used relative to sawdust mulch.

652 The municipal yard debris compost used in the study as part of a mulching program was

653 nutrient rich, increased soil organic matter and helped mitigate the decline in soil $\mathrm{pH}$ that

654 occurred with fertilization over the 8-year study. However, the estimated $25 \mathrm{~kg} \cdot \mathrm{ha}^{-1} \mathrm{~N}$ per year

655 released by the compost was either not available to the plants or was in excess of the $\mathrm{N}$ required,

656 even at the lower rate of fertilizer $\mathrm{N}$ applied. The compost in the mulch increased soil and leaf $\mathrm{K}$

657 in most years. We continue to evaluate whether sustained compost use as part of a fertilization

658 and mulching program may lead to an imbalance in soil cations and adversely affect blueberry

659 plant health. When unmodified yard debris compost (not acidified) was added as a pre-plant

660 amendment, soil $\mathrm{pH}$ increased above the recommended range for blueberry, reducing plant 
661 growth and yield in some cultivars. Yard debris compost must thus be used with caution in

662 blueberry production systems considering the possible increase in weed management costs when

663 used as a mulch and the possible impacts on soil $\mathrm{pH}$ (unless first acidified), when used as an

664 amendment, and K content.

The blueberry cultivars studied responded differently to fertilizer source and rate during

666 establishment and maturation suggesting that cultivar-specific trials would be of benefit in this

667 crop. In our study, 'Duke' which is considered a more difficult cultivar to grow in conventional

668 systems, was also the more sensitive to fertilizer source and rate and soil $\mathrm{pH}$ in the organic

669 systems trials we studied.

670 When we began our blueberry research, the most common production system used in

671 organic fields was growing plants on raised beds, mulching with sawdust and fertilizing with

672 high rates of fish emulsion. Our research results have confirmed that growing on raised beds is

673 advised. However, organic production systems including weed mat and feather meal as the

674 fertilizer source (at the low or high rate of $\mathrm{N}$ ) performed better and had greater economic returns

675 than the industry standard of sawdust mulch and fish emulsion. Based in large part on our

676 findings, weed mat has become the most common mulch used since 2009 in organic and

677 conventional plantings. However, organic growers continue to predominantly use fish emulsion,

678 which may be economically applied by fertigation. In our study, yield in the best-performing

679 organic systems has been comparable to those observed in well-managed conventional fields.

680 Some of the trailing blackberry cultivars we evaluated did not achieve commercially

681 acceptable yields in the organic production systems tested. The trailing blackberry cultivars

682 studied had significantly more growth and yield during establishment and maturity when weed

683 control was used. Weed mat was an effective and economical method of weed control in this 
684 type of blackberry which does not produce new primocanes from root buds (only from the

685 crown). In addition, plants grown with weed mat performed better than those in hand-weeded

686 plots. While weed mat did affect soil nutrient content, there was no consistent relationship with

687 leaf nutrient concentration. Blackberry plants grown in non-weeded plots had a higher TSS,

688 likely a result of reduced water content, but produced smaller berries and had about half the yield

689 of plants grown with weed mat.

Withholding irrigation starting after fruit harvest had no impact on yield over two years

691 offering savings in water use, irrigation costs, and reduced weed pressure. In addition, deficit

692 irrigation increased cold hardiness in 'Marion'. More information is needed on root system depth

693 and whether there are differences among cultivars in the ability to access water from deeper parts

694 of the soil profile. In addition, the longer-term impact of deficit irrigation needs to be assessed.

695 Our studies confirmed that trailing blackberry can be grown successfully in organic

696 production systems for the machine-harvested processed market. However, economical yields

697 were only achieved with use of weed mat in our research. At present, there is relatively little

698 weed mat used in blackberry production in Oregon.

699 Risks in organic production are higher than in conventional production. For example,

700 infestation with raspberry crown borer would have reduced the longevity of the blackberry trial

701 planting as there are few organically-approved control methods. Our findings show promise for

702 finding cultivars that are more tolerant to this pest.

703 In contrast to our findings in blueberry, there was little effect of the diverse sources of

704 fertilizer on blackberry plant growth, yield, and fruit quality. However, in addition to N, most of

705 the organic fertilizers studied also contained high amounts of $\mathrm{P}, \mathrm{K}, \mathrm{Ca}$ and $\mathrm{Mg}$, depending on the

706 source and this was often reflected in soil and leaf nutrient concentration. When organic 
707 fertilizers are used, these other nutrients are added whether they are needed by the plants or not.

708 In addition, growers should compare fertilizer sources for the cost per unit of $\mathrm{N}$ applied, as the

709 sources we studied ranged from $\$$ US5.60 to $\$ 17.95 / \mathrm{kg}$. Cost of application may also be a factor

710 as some products are granular and would need to be applied to the in-row area under a weed mat

711 mulch, if used, for most efficient uptake. Application through the drip irrigation was effective for

712 the liquid fish emulsion and corn steep liquor blends we evaluated. However, we did measure a

713 decline in emitter performance over the 2 years of study indicating that drip system flushing and

714 good maintenance would be critical for fertilizer and irrigation efficiency.

715

716 Acknowledgements

717 The author acknowledges the significant contributions of research collaborators [David

718 Bryla (USDA-ARS, HCRU), Dan Sullivan (Dept. Crop \& Soil Sci., OSU), and Luis Valenzuela-

719 Estrada (OSU)], graduate students (Handell Larco, Renee Harkins, Ryan Costello, Javier

720 Fernandez-Salvador, and Emily Dixon), faculty research assistants (Amanda Vance, Gil Buller,

721 and Emily Vollmer), and industry advisory board members [Eric Pond (AgriCare Inc., OR), Joe

722 Bennett (Pacifica Organic Advisors, WA), Jon Umble (Fall Creek Farm \& Nursery, OR), Tom

723 Avinelis (Homegrown Organic Farms \& AgriCare Inc., CA), Derek Peacock (HBF International,

724 OR), Tristan and Verne Gingerich (Gingerich Farms Products Inc., OR), Gary Middleton

725 (Middleton Organic Orchards, WA), Steve Erickson (PanAmerican Berry Growers, OR),

726 Anthony Boutard (Ayers Creek Farm, OR), Chrislyn Particka (formerly Sakuma Bros. Farms,

727 WA), Josh Beam (formerly SunnyRidge/Dole Inc., FL)]. Our team greatly appreciates research

728 funding support provided by the Northwest Center for Small Fruits Research, the USDA

729 National Institute of Food and Agriculture (Formula Grant no. OREI 2008-04443 \& 2010- 
730 01940), the Oregon Blueberry Commission, the Washington Blueberry Commission, and the

731 Oregon Raspberry and Blackberry Commission, as well as our industry contributors.

732

733 
734

735

736

737

738

739

740

741

742

743

744

745

746

747

748

749

750

751

752

753

754

755

756

\section{References}

Bañados, M.P., B.C. Strik, D.R. Bryla, and T.L. Righetti. 2012. Response of highbush blueberry to nitrogen fertilizer during field establishment. I. Accumulation and allocation of fertilizer nitrogen and biomass. HortScience 47:648-655.

Bell, N., E. Nelson, B. Strik, and L. Martin. 1992. Assessment of winter injury to berry crops in Oregon, 1991. Agr. Expt. Sta. Spec. Rpt. 902, Oregon State Univ.

Bell, N.C., B.C. Strik, L.W. Martin. 1995. Effect of primocane suppression date on 'Marion' trailing blackberry. II. Cold hardiness. J. Amer. Soc. Hort. Sci. 120:25-27.

Breakey, E. P. 1963. Biology and control of the raspberry crown borer Bembecia marginata (Harris). Wash. Agric. Exp. Stn. Tech. Bull. 39.

Bryla, D.R. and R.G. Linderman. 2007. Implications of irrigation method and amount of water application on Phytophthora and Pythium infection and severity of root rot in highbush blueberry. HortScience 42:1463-1467.

Bryla, D.R., R.G. Linderman, and W.Q. Yang. 2008. Incidence of Phytophthora and Pythium infection and the relation to cultural conditions in commercial blueberry fields. HortScience 43:260-263.

Bryla, D.R. and R.M.A. Machado. 2011. Comparative effects of nitrogen fertigation and granular fertilizer application on growth and availability of soil nitrogen during establishment of highbush blueberry. Frontiers Plant Sci. 2:1-8.

Burkhard, N., D. Lynch, D. Percival, and M. Sharifi. 2009. Organic mulch impact on vegetation dynamics and productivity of highbush blueberry under organic production. HortScience $44: 688-696$. 
757 Bushway, L., M. Pritts, and D. Handley (eds.). 2008. Raspberry \& blackberry production guide 758 for the northeast, midwest, and eastern Canada. Plant and Life Sci. Pub., NRAES-35. Ithaca, $759 \quad$ NY.

760 Choi, H-S, C.R. Rom, and M. Gu. 2011. Plant performance, and seasonal soil and foliar nutrient 761 variations in an organic apple orchard under four ground cover management systems. J. 762 Amer. Pom. Soc. 65:130-146.

763 Costello, R.C. 2011. Compost acidification increases growth and nutrient uptake of highbush 764 blueberry under a low N fertilizer regime. M.S. Thesis, Ore. St. Univ., Corvallis, OR. 20 765 May 2015. http://hdl.handle.net/1957/26590

766 Cummings, G., C. Bickford, and L. Nelson. 1971. Fertilizer and lime rates influence highbush 767 blueberry growth and foliar elemental content during establishment. J. Amer. Soc. Hort. $768 \quad$ Sci. $96: 184-186$.

769 DeFrancesco, J., B. Edmunds, and N. Bell. 2015. Cane fruit pests: Raspberry crown borer. In 770 Hollingsworth, C.S., editor. Pacific Northwest Insect Management Handbook [online]. 771 Corvallis, OR: Oregon State University. 4 Apr. 2015.

772 http://insect.pnwhandbooks.org/small-fruit/cane-fruit/cane-fruit-raspberry-crown-borer.

773 Dixon, E.K. and B.C. Strik. 2015. Weed control increases growth, cumulative yield, and 774 economic returns of machine-harvested organic trailing blackberry. Acta Hort. (in press).

775 Dixon, E.K., B.C. Strik, L.R. Valenzuela-Estrada, and D.R. Bryla. 2015. Weed management, 776 training, and irrigation practices for organic production of trailing blackberry: I. Mature 777 plant growth and fruit production. HortScience 50:1165-1177. 
778 Echeverría, V.G., J.V. Cañumir, and H.G. Serri. 2009. Postharvest behavior of highbush

779 blueberry fruits cv. O'Neal cultivated with different organic fertilization treatments.

$780 \quad$ Chilean J. Agr. Res. 69:391-399.

781 Eck, P. 1988. Blueberry science. Rutgers Univ. Press, NewBrunswick, N.J. p. 135-169.

782 Fernandez-Salvador, J., B.C. Strik, and D.R. Bryla. 2015a. Liquid corn and fish fertilizers are

783 good options for fertigation in blackberry cultivars grown in an organic production $784 \quad$ system. HortScience 50:225-233.

785 Fernandez-Salvador, J.A., B.C. Strik, and D. Bryla. 2014b. Response of Blackberry Cultivars to 786 Fertilizer Source in an Organic Fresh Market Production System. HortTechnology $787 \quad 25: 277-292$.

788 Fernandez-Salvador, J., B.C. Strik, Y. Zhao, and C.E. Finn. 2015c. Trailing blackberry 789 genotypes differ in yield and post-harvest fruit quality during establishment in an organic 790 production system. HortScience 50:240-246.

791 Finn, C.E. and B.C. Strik. 2014. Blackberry cultivars for Oregon. Oregon. Ore. State Univ. Ext. 792 Serv. EC 1617. 20 Apr. 2015.

793 https://catalog.extension.oregonstate.edu/files/project/pdf/ec1617.pdf

794 Forge, T.A., E. Hogue, G. Neilsen, and D. Neilsen. 2003. Effects of organic mulches on soil 795 microfauna in the root zone of apple: implication for nutrient fluxes and functional diversity 796 of the soil food web. Appl. Soil Ecol. 22:39-54.

797 Gale, E.S., D.M. Sullivan, D. Hemphill, C.G. Cogger, A.I. Bary, and E.A. Myhre. 2006.

798 Estimating plant-available nitrogen release from manures, composts, and specialty products.

799 J. Environ. Qual. 35:2321-2332. 
800 Granatstein, D. and K. Mullinix. 2008. Mulching options for northwest organic and 801 conventional orchards. HortScience 43:45-50.

802 Hanson, E.J. 2006. Nitrogen nutrition of highbush blueberry. Acta Hort. 715:347-351.

803 Harkins, R.H. 2013. Weed, water, and nutrient management practices for organic blackberry

804 production. M.S. Thesis, Ore. St. Univ., Corvallis. 15 July 2013.

$805<$ http://ir.library.oregonstate.edu/xmlui/bitstream/handle/1957/40102/HarkinsReneeH2013.p

$806 \quad$ df?sequence=1>.

807 Harkins, R.H., B.C. Strik, and D.R. Bryla. 2013. Weed management practices for organic

808 production of trailing blackberry: I. Plant growth and early fruit production. HortScience

$809 \quad$ 48:1139-1144.

810 Harkins, R.H., B.C. Strik, and D.R. Bryla. 2014. Weed management practices for organic

811 production of trailing blackberry: II. Accumulation and loss of biomass and nutrients.

$812 \quad$ HortScience 49:35-43.

813 Hart, J., B. Strik, and H. Rempel. 2006a. Caneberries. Nutrient management guide. Oregon State

814 Univ. Ext. Serv., EM8903-E. Corvallis, OR. 20 Apr. 2015.

815 http://ir.library.oregonstate.edu/xmlui/bitstream/handle/1957/20427/em8903-e.pdf

816 Hart, J., B. Strik, L. White, and W. Yang. 2006b. Nutrient management for blueberries in

817 Oregon. Ore. State Univ. Ext. Serv. EM 8918. 20 Apr. 2015.

818 http://ir.library.oregonstate.edu/xmlui/bitstream/handle/1957/20444/em8918.pdf

819 Judd, G.J.R., R. Gries, C. Teasdale, and G. Gries. 2012. Identification of a sex pheromone

820 component for Pennisetia marginata (Lepidoptera: Sesiidae). Can. Entomol. 144:798-807. 
821 Julian, J., B. Strik, and W. Yang. 2011a. Blueberry economics: The costs of establishing and

822 producing blueberries in the Willamette Valley, Oregon. AEB 0022, 25pp.

823 http://arec.oregonstate.edu/oaeb/files/pdf/AEB0022.pdf

824 Julian, J., B. Strik, E. Pond., and W. Yang. 2011b. Blueberry economics: The costs of

825 establishing and producing organic blueberries in the Willamette Valley, Oregon. Oregon

826 State Univ. Pub. AEB 0023, 25 pp. http://arec.oregonstate.edu/oaeb/files/pdf/AEB0023.pdf

827 Julian, J.W., B.C. Strik, H.O. Larco, D.R. Bryla, and D.M. Sullivan. 2012. Costs of establishing

828 organic northern highbush blueberry: Impacts of planting method, fertilization, and mulch

829 type. HortScience 47:1-8.

830 Krewer, G. and J. Ruter. 2012. Fertilizing bushes three years and older, p. 5. In: Fertilizing

831 highbush blueberries in pine bark beds. Univ. Ga. Coop. Ext. Bull. 1291.

832 Krewer, G. and R. Walker. 2006. Suggestions for organic blueberry production in Georgia. Univ.

833 Ga. Ext. Fruit Publ. 00-1.

834 http://www.smallfruits.org/Blueberries/production/06organicblues.pdf

835 Krewer, G., M. Tertuliano, P. Andersen, O. Liburd, G. Fonsah, H. Serri, and B. Mullinix. 2009.

836 Effect of mulches on the establishment of organically grown blueberries in Georgia. Acta

837 Hort. 810:483-488.

838 Kuepper, G.L., H. Born, and J. Bachmann. 2003. Organic culture of bramble fruits. ATTRA

839 publication, IP022. (http://attra.ncat.org/attra-pub/bramble.html)

840 Kuepper, G.L. and S. Diver. 2004. Blueberries: Organic production. ATTRA.

$841 \quad$ www.attra.ncat.org 
842 Larco, H.O. 2010. Effect of planting method, weed management, and fertilizer on plant growth 843 and yield of newly established organic highbush blueberries. MS thesis, Oregon State Univ., 844 Corvallis. http://ir.library.oregonstate.edu/xmlui/handle/1957/18065

845 Larco, H., D.M. Sullivan, B. Strik, and D. Bryla. 2014. Mulch effects on highbush blueberry 846 under organic management. Acta Hort. 1018:375-382.

847 Larco, H., B.C. Strik, D.R. Bryla, and D.M. Sullivan. 2013a. Weed and fertilizer management 848 practices for organic production of highbush blueberries-I. Early plant growth and biomass 849 allocation. HortScience 48:1250-1261.

850 Larco, H., D.R. Bryla, B.C. Strik, and D.M. Sullivan. 2013b. Weed and fertilizer management 851 practices for organic production of highbush blueberries-II. Impact on plant and soil 852 nutrients, yield, and fruit quality during establishment. HortScience 48:1484-1495.

853 Makus, D.J. 2011. Use of synthetic ground covers to control weeds in blackberries. Int. J. Fruit 854 Sci. 11:286-298.

855 Malik, H., D.D. Archbold, and C.T. MacKown. 1991. Nitrogen partitioning by 'Chester 856 Thornless' blackberry in pot culture. HortScience 26:1492-1494.

857 Meyers, S.L., K.M. Jennings, D.W. Monks, and W.E. Mitchem. 2014. Effect of weed-free strip 858 width on newly established 'Navaho' blackberry growth, yield, and fruit quality. Weed 859 Technol. 28:426-431.

860 Mohadjer, P., B.C. Strik, B.J. Zebarth, and T.L. Righetti. 2001. Nitrogen uptake, partitioning and 861 remobilization in 'Kotata' blackberry in alternate-year production. J. Hort. Sci. Biotechnol. $862 \quad 76: 700-708$.

863 Naraguma, J., and J.R. Clark. 1998. Effect of nitrogen fertilization on 'Arapaho' thornless 864 blackberry. Commun. Soil Sci. Plant Anal. 29:2775-2783. 
865 Retamales, J.B. and E.J. Hanson. 1989. Fate of ${ }^{15} \mathrm{~N}$-labeled urea applied to mature highbush 866 blueberries. J. Amer. Soc. Hort. Sci. 114:920-923.

867 Sciarappa, W., S. Polavarapu, J. Barry, P. Oudemans, M. Ehlenfeldt, G. Pavlis, D. Polk, and R.

868 Holdcraft. 2008. Developing an organic production system for Highbush Blueberry.

$869 \quad$ HortScience 43:51-57.

870 Strik, B.C. 2014. Organic blueberry production systems - advances in research and industry. $871 \quad$ Acta Hort. 1017:257-267.

872 Strik, B. and G. Buller. 2002. Improving yield and machine harvest efficiency of 'Bluecrop' 873 through high-density planting and trellising. Acta Hort. 574:227-231.

874 Strik, B.C. and C.E. Finn. 2012. Blackberry production systems - a worldwide perspective. Acta $875 \quad$ Hort. 946:341-348.

876 Strik, B.C. and A. Vance. 2015. Seasonal variation in leaf nutrient concentration of northern 877 highbush blueberry cultivars grown in conventional and organic production systems. $878 \quad$ HortScience 50:1453-1466.

879 Strik, B.C. and D. Yarborough. 2005. Blueberry production trends in North America, 1992 to 2003 and predictions for growth. HortTechnology 15:391-398.

881 Strik, B.C., C.E. Finn, and P.P. Moore. 2014. Blueberry cultivars for the Pacific Northwest.

882 Oregon. Ore. State Univ. Ext. Serv. PNW 656. 20 Apr. 2015.

883 http://ir.library.oregonstate.edu/xmlui/bitstream/handle/1957/45871/pnw656.pdf

884 Strik, B.C., A. Vance, and D. Bryla. 2015. Organic production systems research in blueberry and 885 blackberry - A review of industry-driven studies. Acta Hort. (in press).

886 Strik, B.C., J.R. Clark, C.E. Finn, and P. Bañados. 2007. Worldwide production of blackberries, 8871995 to 2005 and predictions for growth. HortTechnology 17:205-213. 
Sullivan, D.M., A.I. Bary, T.J. Nartea, E.A. Myrhe, C.G. Cogger, and S.C. Fransen. 2003. Nitrogen availability seven years after a high-rate food waste compost application. Compost Sci. Util. 11: 265-275.

Sullivan, D.M., B.C. Strik, and D. Bryla. 2015. Evaluation of alternative mulches for blueberry over five production seasons. Acta Hort. 1076:171-178.

Takele, E., B. Faber, M. Gaskell, G. Nigatu, and I. Sharabeen. 2007. Sample costs to establish and produce organic blueberries in the coastal region of Southern California, San Luis Obispo, Santa Barbara, and Ventura Counties, 2007. Univ. Cal. Coop. Ext., BR-SC-07-O.

Teasdale, C., G.J.R. Rudd, R. Gries, and G. Gries. 2013. Evaluation of synthetic sex pheromone for monitoring and management of raspberry crown borer Pennisetia marginata (Lepidoptera: Sesiidae). Agric. For. Entomol. 15:285-293.

Tertuliano, M. G. Krewer, J.E. Smith, K. Plattner, J. Clark, J. Jacobs, E. Andrews, D. Stanaland, P. Andersen, O. Liburd, E.G. Fonsah, and H. Scherm. 2012. Growing organic rabbiteye blueberries in Georgia, USA: Results of two multi-year field studies. Inter. J. Fruit Sci. $12: 205-215$.

Throop, P.A. and E.J. Hanson. 1997. Effect of application date on absorption of ${ }^{15}$ nitrogen by highbush blueberry. J. Amer. Soc. Hort. Sci. 122:422-426.

U.S. Department of Agriculture. 2014. Table 33: Berries: 2012 and 2007. In: 2012 Census of Agriculture. U.S. Dept. Agr., Natl. Agr. Statistical Serv., Washington, DC.

U.S. Department of Agriculture. 2010. Table 6: Organic berries harvested from certified and exempt organic farms: 2008. In: Organic production survey (2008), 2007 Census of agriculture. U.S. Dept. Agr., Natl. Agr. Statistical Serv., Washington, DC. 
910 Valenzuela-Estrada, L.R., D.R. Bryla, D.M. Sullivan, and B.C. Strik. 2011a. Influence of weed

911 mat and surface sawdust mulch on soil nutrient availability and soil chemical properties

912 under organic blueberry production. Amer. Soc. Hort. Sci. Abstr.

$913 \quad$ <https://ashs.confex.com/ashs/2011/webprogram/Paper7426.html>.

914 Valenzuela-Estrada, L.R., D.R. Bryla, D.M. Sullivan, and B.C. Strik. 2011b. Organic blueberry

915 research project: roots. eOrganic. <http://www.extension.org/pages/32763/organic-

$916 \quad$ blueberry-production-research-project:-roots

917 Wang, S.Y., C-T Chen, W. Sciarappa, C.Y. Wang, and M.J. Camp. 2008. Fruit quality,

918 antioxidant capacity, and flavonoid content of organically and conventionally grown

919 blueberries. J. Agric. Food Chem. 56:5788-5794.

920 You, Q., B. Wang, F. Chen, Z. Huang, X. Wang, and P.G. Luo. 2011. Comparison of

921 anthocyanins and phenolics in organically and conventionally grown blueberries in

$922 \quad$ selected cultivars. Food Chem. 125:201-208.

923

924 
925 Table 1. Total nutrients applied in various sources of fertilizer and mulches used in organic blackberry and blueberry research trials

926 conducted at Oregon State University's North Willamette Research and Extension Center, Aurora, Oregon, USA.

\begin{tabular}{|c|c|c|c|c|c|c|c|c|c|c|c|c|}
\hline \multirow[b]{2}{*}{ Product } & \multicolumn{6}{|c|}{ Macronutrients $\left(\mathrm{kg} \cdot \mathrm{ha}^{-1}\right)$} & \multicolumn{6}{|c|}{ Micronutrients $\left(\mathrm{kg} \cdot \mathrm{ha}^{-1}\right)$} \\
\hline & $\mathrm{N}^{2}$ & $\mathrm{P}$ & $\mathrm{K}$ & $\mathrm{Ca}$ & $\mathrm{Mg}$ & $\mathrm{Na}$ & B & $\mathrm{Fe}$ & Mn & $\mathrm{Cu}$ & $\mathrm{Zn}$ & $\mathrm{Al}$ \\
\hline \multicolumn{13}{|l|}{ Fertilizer products ${ }^{y}$} \\
\hline Poultry litter ${ }^{x}$ & 53 & 31 & 36 & 161 & 10 & 6 & 0.1 & 0.2 & 0.6 & 0.1 & 0.6 & 0.4 \\
\hline Soybean meal ${ }^{\mathrm{x}, \mathrm{w}}$ & 49 & 4 & 17 & 2 & 2 & 0 & 0 & 0.1 & 0 & 0 & 0.1 & 0.1 \\
\hline Fish emulsion $^{\mathrm{x}, \mathrm{w}}$ & 53 & 8 & 63 & 1 & 1 & 26 & 0 & 0.4 & 0 & 0 & 0.1 & 0.1 \\
\hline Grain fermentation $^{\mathrm{x}}$ & 40 & 22 & 27 & 3 & 6 & 1 & 0 & 0.7 & 0 & 0 & 0 & - \\
\hline Corn Steep liquor ${ }^{\mathrm{x}}$ & 62 & 30 & 40 & 3 & 8 & 1 & 0 & 0 & 0 & 0 & 0 & - \\
\hline Feather meal $^{\mathrm{w}}$ & 50 & 1 & 2 & 3 & 0 & 0 & 0 & 0.4 & 0 & 0 & 0.3 & - \\
\hline \multicolumn{13}{|l|}{ Mulch products ${ }^{\mathrm{v}}$} \\
\hline Sawdust & 69 & 5 & 22 & 30 & 6 & - & 2.2 & - & 1.4 & 0.1 & 0.3 & - \\
\hline $\begin{array}{l}\text { Yard-debris } \\
\text { compost }\end{array}$ & 615 & 97 & 342 & 613 & 143 & - & 2.0 & - & 27.1 & 0.2 & 6.6 & - \\
\hline
\end{tabular}

927

$928{ }^{\mathrm{z}} \mathrm{N}=$ nitrogen $\mathrm{P}=$ phosphorus $; \mathrm{K}=$ potassium $; \mathrm{Ca}=$ calcium $; \mathrm{Mg}=$ magnesium $; \mathrm{Na}=$ sodium $; \mathrm{B}=\mathrm{boron} ; \mathrm{Fe}=$ iron$; \mathrm{Mn}=$

929 manganese; $\mathrm{Cu}=$ copper; $\mathrm{Zn}=$ zinc; $\mathrm{Al}=$ aluminum.

$930{ }^{\mathrm{y}}$ All products were applied at the same target rate of $\mathrm{N}\left(56 \mathrm{~kg} \cdot \mathrm{ha}^{-1}\right)$ based on the product label. Fertilizers were analyzed for elemental

931 content by Brookside Laboratories (New Bremen, OH), and actual calculated rate of elements applied is presented here. "Poultry

932 litter”: pelletized and processed, Nutri-Rich 4-3-3 (4N-1.3P-2.5K-7Ca; Stutzman Environmental Products, Canby, OR). “Soybean 
meal”: pelletized, Leafy Green 8-1-2 (“soy”; 8N-0.4P-1.7K; California Organic Fertilizers, Hanford, CA). "Fish emulsion”: fish hydrolysate and fish emulsion with added molasses mixture (fertigated after diluting with water 1:10 v/v), TRUE 4-0-2 (4N-0P1.7K; True Organic Products, Spreckels, CA). "Grain fermentation": grain fermentation soluble and sodium nitrate (fertigated after diluting with water 4:1 v/v), 4-2-1 (Converted Organics of California, LLC, Gonzales, CA). “Corn steep liquor”: corn steep liquor and ground fish waste blend (fertigated after diluting with water 1:2, v/v), Agrothrive LF (2.5N-1.1P-1.2K; AgroThrive, Inc., Morgan Hill, CA). "Feather meal": Phyta-Grow Super "N" (12N-0P-0K; California Organic Fertilizers, Hanford, CA). Nutri-Rich 4-3-3 had a pH of 8.3, TRUE 4-0-2 had a pH of 5.5, Leafy Green 8-1-2 had a pH of 6.2, Converted organics 4-2-1 had a pH of 4.1, Agrothrive LF 2.5N-1.1P-1.2K had a pH of 3.98, and Phyta-Grow super "N" had a pH of 7.0. Adapted from Fernandez-Salvador et al. (2015b, 2015c) and Strik and Vance (unpublished).

\section{${ }^{\mathrm{x}}$ Used successfully in organic blackberry research trials.}

\section{${ }^{\mathrm{w}}$ Used successfully in organic blueberry research trials.}

VNutrients for the volume applied in 2013 as follows: "Sawdust": Douglas fir (Pseudostsuga menziesii M.) applied to the in-row area at a depth of $9 \mathrm{~cm}\left(360 \mathrm{~m}^{3} \cdot \mathrm{ha}^{-1}\right), \mathrm{pH} 4.1$. "Yard-debris compost": municipal waste from yards, composted, applied to a depth of $4 \mathrm{~cm}$ to the in-row area $\left(152 \mathrm{~m}^{3} \cdot \mathrm{ha}^{-1}\right), \mathrm{pH}$ 7.5. Strik and Vance (unpublished). 

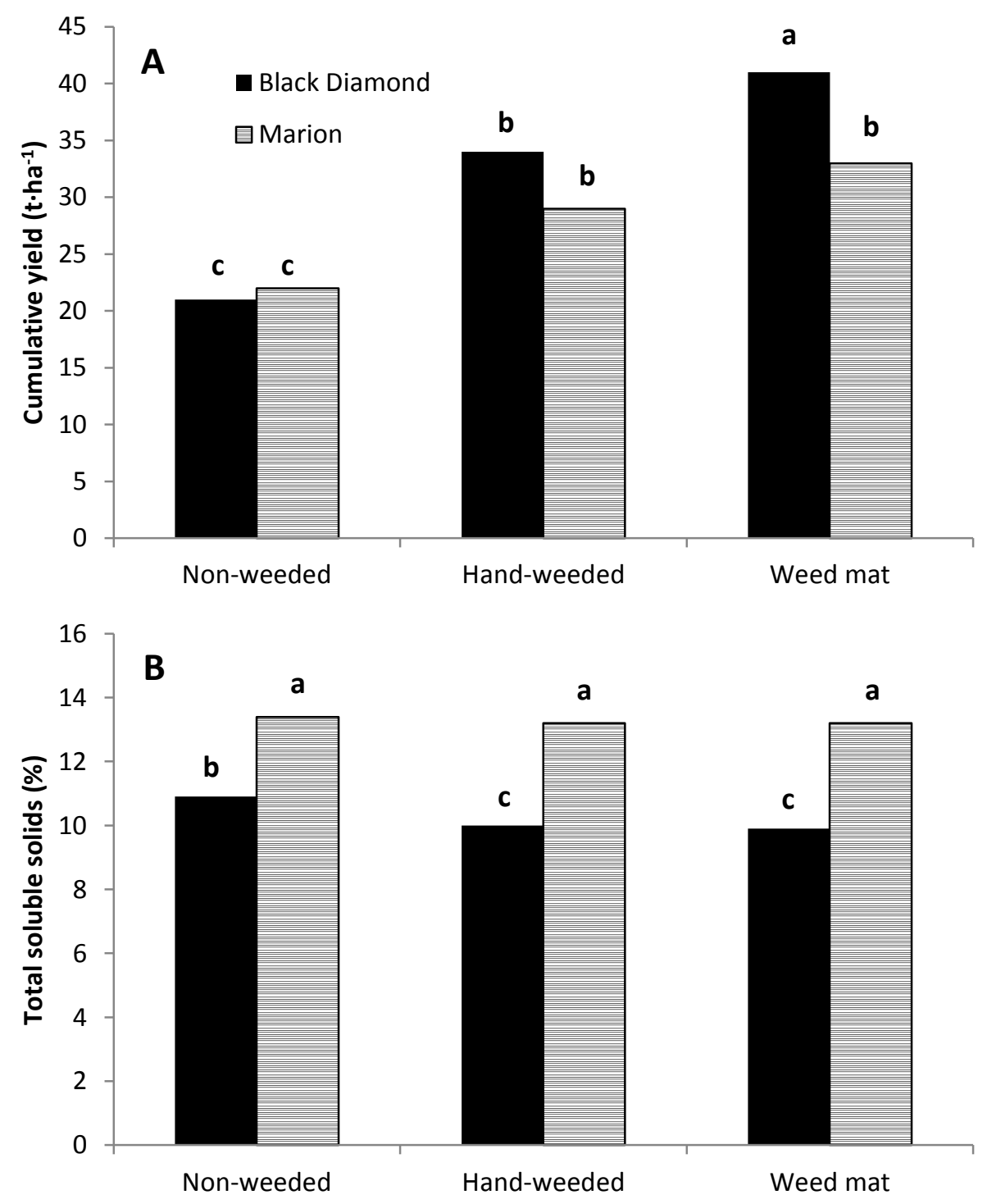

949 Fig. 1. Impact of three weed management strategies on A. cumulative yield (2012-2014) and B.

950 fruit total soluble solids (TSS) of trailing blackberry cultivars Black Diamond and Marion grown

951 in a certified organic machine-harvested research trial at Oregon State University's North

952 Willamette Research and Extension Center, Aurora, Oregon, USA. Averaged over training time

953 and post-harvest irrigation treatments. Letters above bars indicate mean comparison $(P<0.05 ; \mathrm{n}$

$954=10)$ using a protested LSD test.

955 

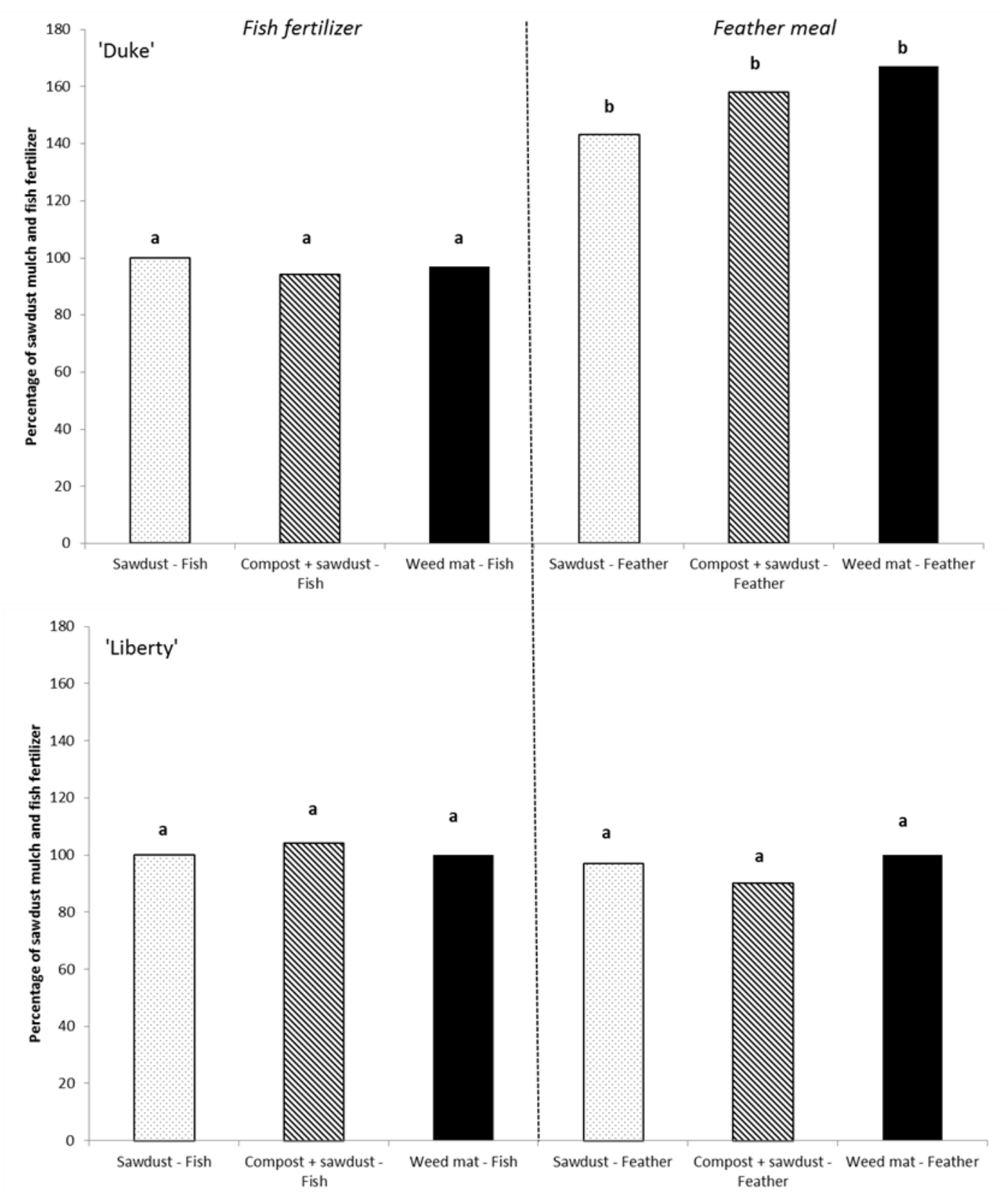

Fig. 2. Effect of mulch type (sawdust, compost + sawdust, and weed mat) and fertilizer source

959 (fish emulsion or feather meal applied at the same "high" rate of N) on cumulative yield (2008-

960 2014) of 'Duke' and 'Liberty' grown on raised beds. Yield is shown as the proportion of each

961 treatment combination (\%) relative to the industry standard (sawdust mulch and fish fertilizer;

$962100 \%)$. Letters above bars indicate mean comparison within cultivar $(P<0.05 ; \mathrm{n}=5)$, using a

963 protected LSD test. 